\title{
Dyeing Wool Fiber with Natural Alizarin in a Vat System
}

\section{Younes Chemchame, Mohamed EI Moudden, Anass Mansar}

Department of Traditional Weaving, Academy of Traditional Arts, Foundation of Hassan II Mosque, Casablanca, Morocco

\section{Email address:}

ychem2@gmail.com (Y. Chemchame)

\section{To cite this article:}

Younes Chemchame, Mohamed El Moudden, Anass Mansar. Dyeing Wool Fiber with Natural Alizarin in a Vat System. American Journal of Applied Chemistry. Vol. 4, No. 5, 2016, pp. 170-173. doi: 10.11648/j.ajac.20160405.12

Received: July 24, 2016; Accepted: August 3, 2016; Published: August 21, 2016

\begin{abstract}
Herein we report our study on wool dyeing with natural alizarin in a vat system using the Argan's pulp. Natural alizarin was extracted from the Rubia tinctorum plant using enzymatic hydrolysis and alkaline solution. In order to assess the role of the reducer in the dyeing process, we tested one dye bath without reducer containing just alizarin extract and sodium carbonate solution at $\mathrm{pH}$ 8. In the vat preparation using these components, we used Argan's pulp as the reducer. Under relatively soft dyeing conditions for wool $\left(60^{\circ} \mathrm{C}\right.$ and $\left.\mathrm{pH} 8\right)$ dyeing in the vat system realized a higher degree of dye fixation and wash fastness.
\end{abstract}

Keywords: Argan's Pulp, Natural Alizarin, Rubia Tinctorum, Vat System, Wool

\section{Introduction}

Alizarin is the most well-known anthraquinone isolated from madder. In 1826 alizarin was first isolated from Rubia tinctorum by Colin and Robiquet [1]. After the first isolation of alizarin many other anthraquinones were isolated from $R$. tinctorum, for example purpurin, munjistin, rubiadin, pseudopurpurin, nordamnacanthal, lucidin, xanthopurpurin and anthragallol. Ruberythric acid was first isolated in a crystalline form by Rochleder in 1851 [2].

Ruberythric acid consists of the alizarin aglycone and a disaccharide (primeverose: glucose and xylose). The anthraquinone alizarin, the hydrolysis product of ruberythric acid, is known to be the main dye component of $R$. tinctorum [3].

In this study, we have used enzymatic hydrolysis (endogenous conversion) to convert the glucosidic anthraquinones, in particular, ruberythric acid to alizarin [4] (see paragraph: Preparation of dye baths A1 and B1).<smiles>O=C1c2ccccc2C(=O)c2ccccc21</smiles>

Non-soluble pigment

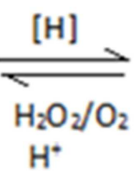

$\mathrm{H}^{+}$<smiles>OC1=C2C=CC=CC2C(O)=C2C=CC=CC12</smiles>

Non-soluble leuco acid

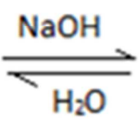<smiles>[N+]OC1=C2C=CC=CC2[N+](O[N-])=C2C=CC=CC12</smiles>

Soluble leuco derivative

Figure 1. Reduction and Oxidation reactions of anthraquinonic dye. 
At first, the dye is converted into its reduced form known as leuco acid, which is not soluble in water and has low substantivity to the fiber. After the addition of alkali, the leuco acid is converted to a water soluble leuco derivative, which has a higher substantivity to the fiber.

The reducer was chosen from Argan's pulp as a local plentiful product, which contains an important quantity of reducer sugar. The redox potential of the reducer sugar ranges from 245-700 $\mathrm{mV}$ dependent on the dyeing temperature [8].

\section{Experimental}

\subsection{Materials}

\subsubsection{Features of Wool Fiber}

The wool fiber used was obtained from the Boujaâd city region of Morocco. White fleece was compacted and homogenized into a medium weight fleece $1.5-3 \mathrm{~kg}$ and the fineness of the fiber was 50-60 using the Bradford scale [9].

\subsubsection{Natural Dye}

The dye used in the present study was from a natural source and extracted from the $R$. tinctorium plant, which grows in the South-East of Morocco [10]. The extraction method was based on enzymatic hydrolysis (endogenous conversion) of the dried and powdered root of the plant.

\subsubsection{Argan's Pulp}

The reducer agent, Argan's pulp, was collected from around the Argan tree from the Essaouira city region of South Morocco. This natural source was composed of $20 \%$ reducer sugar, $13 \%$ cellulose, $6 \%$ protein, $2 \%$ fat and $4 \%$ latex (comprised of $86 \%$ of cis-polyisoprene: rubber) [9, 11, 12].

\subsubsection{Alkali Agent}

The alkali agent used, sodium carbonate $\left(\mathrm{Na}_{2} \mathrm{CO}_{3}\right)$, was of analytical grade and obtained from Lobachemie company Mumbai (India).

\subsubsection{Common Salt}

The common salt used, sodium chlorate $(\mathrm{NaCl})$, was of technical grade and obtained from the customary magazine.

\subsubsection{Spectrophotometer}

The ultraviolet-visible (UV-vis) spectrophotometer used in this study was a Thermo, Helios Epsilon model. The wavelength range was $325-1100 \mathrm{~nm}$ with a spectral bandwidth of $1 \mathrm{~nm}$.

\subsection{7. pH Meter}

The $\mathrm{pH}$ meter used was a Henne, AD1000 model. It is the multimeter with professional banc for $\mathrm{pH}$, redox (oxydo-reduction potential) and temperature measurements.

\subsubsection{Vat/Bath}

The vat/bath used was a $250 \mathrm{~mL}$ flask format. Heating was provided using a thermostat hotplate, Scilogex MS-H280-Pro.

\subsubsection{Filter}

Two types of filter were used in this study, a metallic sieve (diameter 1-5 $\mathrm{mm}$ ) and Büchner funnel with water trumped.

\subsection{Preparation of the Reducer}

Two solutions were prepared at different concentrations: $6 \mathrm{~g}$ (dye bath A1) and $2 \mathrm{~g}$ (dye bath B1) of Argan's pulp were added separately in $500 \mathrm{~mL}$ of distilled water and heated at $95^{\circ} \mathrm{C}$ for $30 \mathrm{~min}$. The extract was filtrated using the metallic sieve.

\subsection{Dyeing Process}

\subsubsection{Preparation of Dye Baths $A 1$ and $B 1$}

Two quantities of $2.5 \mathrm{~g}$ of the plant was stirred separately in $100 \mathrm{~mL}$ of water at $45^{\circ} \mathrm{C}$. After $1 \mathrm{~h}$, solutions of $0.1 \mathrm{~g} / \mathrm{L}$ (dye bath $\mathrm{A} 1$ ) and $0.2 \mathrm{~g} / \mathrm{L}$ (dye bath B1) of sodium carbonate $\left(\mathrm{Na}_{2} \mathrm{CO}_{3}\right)$ were added to the two prepared solutions. The $\mathrm{pH}$ of the solution was adjusted to 8 (dye bath A1) and 9 (dye bath B1), respectively, which gave a color change from yellow to purple. Water was added to both of the prepared solutions to make them up to a volume of $500 \mathrm{~mL}$, which were designated as the original solution of dye bath $\mathrm{A} 1$ and original solution of dye bath $\mathrm{B} 1$, respectively. Two fractions of $100 \mathrm{~mL}$ were extracted. $10 \mathrm{~mL}$ (dye bath $\mathrm{A} 1$ ) and $5 \mathrm{~mL}$ (dye bath $\mathrm{B} 1$ ) of Argan's pulp extract (described above) were be added to each one of these fractions solutions and stirred for $30 \mathrm{~min}$ at $45^{\circ} \mathrm{C}$. The both fractions were be filtered through a Buchner funnel and designated dye bath A1 and dye bath B1, respectively.

\subsubsection{Preparation of Dye Baths $A 2$ and $B 2$}

Two fractions of $100 \mathrm{~mL}$ were extracted from both initial solutions of dye bath $\mathrm{A} 1$ and $\mathrm{B} 1$. The $\mathrm{pH}$ of these fractions were 8 (dye bath A1) and 9 (dye bath B1) as described above. The solutions were stirred for $30 \mathrm{~min}$ at $45^{\circ} \mathrm{C}$. Then, both fractions were filtered through a Buchner funnel and designated dye bath $\mathrm{A} 2$ and dye bath $\mathrm{B} 2$.

\subsubsection{Dyeing Conditions}

i. Dye bath A1:

- Dye: $100 \mathrm{~mL}$ of extract prepared from $2.5 \mathrm{~g}$ of $R$. tinctorum stirred in $500 \mathrm{~mL}$ of water.

- Reducer: $10 \mathrm{~mL}$ (of Argan's pulp extract containing $6 \mathrm{~g}$ of Argan's pulp in $500 \mathrm{~mL}$ of water).

- Sodium carbonate: $0.1 \mathrm{~g} / \mathrm{L}(\mathrm{pH}=8)$.

- Sodium chlorate: $5 \mathrm{~g} / \mathrm{L}$.

- Temperature: $45^{\circ} \mathrm{C}$.

- Time: 30 min.

- Liquor rato: $1 / 100$.

ii. Dye bath A2:

- Dye: $100 \mathrm{~mL}$ of extract prepared from $2.5 \mathrm{~g}$ of $R$. tinctorum stirred in $500 \mathrm{~mL}$ of water.

- Sodium carbonate: $0.1 \mathrm{~g} / \mathrm{L}(\mathrm{pH}=8)$.

- Sodium chlorate: $5 \mathrm{~g} / \mathrm{L}$.

- Temperature: $45^{\circ} \mathrm{C}$. 
- Time: $30 \mathrm{~min}$

- Liquor rato: $1 / 100$.

iii. Dye bath B1:

- Dye: $100 \mathrm{~mL}$ of extract prepared from $2.5 \mathrm{~g}$ of $R$. tinctorum stirred in $500 \mathrm{~mL}$ of water.

- Reducer: $5 \mathrm{~mL}$ of Argan's pulp extract containing $2 \mathrm{~g}$ of Argan's pulp in $500 \mathrm{~mL}$ of water.

- Sodium carbonate: $0.2 \mathrm{~g} / \mathrm{L}(\mathrm{pH}=9)$.

- Temperature: $45^{\circ} \mathrm{C}$.

- Time: $30 \mathrm{~min}$.

- Liquor rato: $1 / 100$.

iv. Dye bath B2:

- Dye: $100 \mathrm{~mL}$ of extract prepared from $2.5 \mathrm{~g}$ of $R$. tinctorum stirred in $500 \mathrm{~mL}$ of water.

- Sodium carbonate: $0.2 \mathrm{~g} / \mathrm{L}(\mathrm{pH}=9)$.

- Temperature: $45^{\circ} \mathrm{C}$.

- Time: 30 min.

- Liquor rato: $1 / 100$.

The forth samples of wool (1 g) were soaked and wrung before being involved in the dyeing baths.

v. Oxidation and rinsing

The oxidation was realized in the open air for $15 \mathrm{~min}$ for the both rinsing phases.

The rinse was realized (for the forth samples) at the end of the dyeing process as presented below:

- $1^{\text {st }}$ rinse in cold water.

- $2^{\text {nd }}$ rinse in cold water, the $\mathrm{pH}$ measured in the residual rinse baths for samples of dye baths A1 and A2 were
7.23 .

- Neutralization with acetic acid to $\mathrm{pH}$ 6, only for samples of dye baths B1 and B2.

- Rinse in hot water $\left(60^{\circ} \mathrm{C}\right)$ for $15 \mathrm{~min}$, in order to delete the no fixed or weakly fixed dyes.

vi. Drying

Drying may be carried out open to air or in a sterile environment at a temperature between $60^{\circ} \mathrm{C}$ and $80^{\circ} \mathrm{C}$.

vii. Spectral analysis

Calibration of the spectrophotometer

Calibration of the spectrophotometer was realized using a standard solution prepared according to the concentration of Argan's pulp, the weight of wool yarn and the concentration of sodium carbonate used in each dye bath.

Measurement of the dye exhaustion and fixation rate

We removed $2 \mathrm{~mL}$ of the solution from each dye bath to be measured. Each sample was diluted to $10 \mathrm{~mL}$ using the prepared standard solutions. The absorbances were measured at wavelength $500 \mathrm{~nm}$.

The absorbance measurements are shown in Table 1 and 2.

\section{Results and Discussion}

\subsection{Exhaustion of Alizarin Dye}

The measurement of exhaustion dye rate is presented in Table 1 .

Table 1. Exhaustion rate of alizarin dye.

\begin{tabular}{llll}
\hline & Absorbance of initial dyebath (Absi) & Absorbance of residual dyebath (Absf) & Exhaustion rate ((Absi-Absf)/Absi)*100 \\
\hline Dye bath A1 & 0.165 & 0.065 & $61 \%$ \\
Dye bath A2 & 0.145 & 0.054 & $63 \%$ \\
Dye bath B1 & 0.150 & 0.088 & $41 \%$ \\
Dye bath B2 & 0.100 & 0.068 & $32 \%$ \\
\hline
\end{tabular}

\subsubsection{Comparison Between Dye Baths $A 1$ and $A 2$}

The exhaustion rates for both samples were quite high when compared to classical dyeing methods. This can due to the addition of salt $(\mathrm{NaCl})$ that increases the dye substantivity to the fiber. Moreover, the difference between the exhaustion rates of dye baths $\mathrm{A} 1$ and $\mathrm{A} 2$ can be explained by the high solubility of alizarin dye in the dye bath using the reducer. The use of a reducer in the dye bath increases the solubility of alizarin dye (Abs A1 =0.165 against Abs A2 =0.145).

\subsubsection{Comparison Between Dye Baths B1 and B2}

The addition of a reducer in the dye bath increases the solubility of alizarin dye (Abs B1 $=0.150$ against Abs B2 $=$ $0.100)$. The difference between the exhaustion rates of dye baths B1 and B2 can be explained by the alkalinity of the dye bath ( $\mathrm{pH} 9)$, which avoids the adsorption of dye into the fiber via electrostatic repulsion (the dye and wool fiber are negatively charged). The reducer at this $\mathrm{pH}$ plays the role of an electrolyte to decrease the electrostatic repulsion between the dye and fiber.

\subsubsection{Comparison Between Dye Baths $A$ and $B$}

The addition of common salt $(\mathrm{NaCl})$ in dye bath A increased the substantivity of alizarin dye towards the fiber. The weak alkalinity of the medium ( $\mathrm{pH} 8$ ) increased the substantivity of dye towards the fiber. This can be used to explain the higher exhaustion value for dye bath A1 and A2 due to the effect of salt.

\subsection{Fixation of Alizarin Dye}

The measurements of the fixed and non-fixed dye rates are presented in Table 2. 
Table 2. Fixation rate of alizarin dye.

\begin{tabular}{llll}
\hline & Absorbance of residual rinse bath at $\mathbf{6 0}^{\circ} \mathbf{C}$ (Absr) & Fixation rate ((Absi-Absf-Absr)/Absi)*100 & Non-fixed dye rate (Absr/Absi)*100 \\
\hline Dye bath A1 & 0.014 & $52 \%$ & $8.5 \%$ \\
Dye bath A2 & 0.021 & $48 \%$ & $14.5 \%$ \\
Dye bath B1 & 0.004 & $39 \%$ & $2.0 \%$ \\
Dye bath B2 & 0.008 & $28 \%$ & $4.0 \%$ \\
\hline
\end{tabular}

\subsubsection{Comparison Between Dye Baths $A 1$ and A2}

The fixation rate of alizarin dye shown in Table 2 was higher using the reducer process (vat system). Moreover, the non-fixed dye rate reveals a big difference in dye fastness using the two dyeing process. Dyeing without a reducer leads to the loss of a large amount of dye. In contrast, the reducer process results in less non-fixed dye. This was attributed to the good diffusion inside the fiber of the dye reducer form and due to the realization of more important physico-chemical interactions (hydrogen bonds) and physical interactions (Van der Waals interactions) with the fiber.

\subsubsection{Comparison Between Dye Baths B1 and B2}

The values mentioned in this experience confirm all the conclusions described beforehand.

\subsubsection{Comparison Between Dye Baths A and B}

The higher fixation rate of dye realized in dye bath $\mathrm{A} 1$ was attributed to the higher quantity of reducer $(12 \mathrm{~g} / \mathrm{L}$ in dye bath A1 against $4 \mathrm{~g} / \mathrm{L}$ in dye bath B1). The non-fixed dyes depend closely on the $\mathrm{pH}$ of the rinse bath. In fact, the non-fixed dye rates for dye bath $\mathrm{B} 1$ and $\mathrm{B} 2$ were lower than dye baths $\mathrm{A} 1$ and $\mathrm{A} 2$ because the $\mathrm{pH}$ of rinse bath $\mathrm{B}$ was 6.0 when compared to the $\mathrm{pH}$ of rinse bath $\mathrm{A}$ at 7.3. This was due to the high solubility of phenols (like alizarin) in an alkaline solution.

\section{Conclusions}

The reducer process insures more fixation and wash fastness of alizarin dye even in slightly alkaline medium. Using Argan's pulp as a plentiful local product allowed a high degree of exhaustion and fixation when compared to other classical dyeing methods. This process can be recorded in a full ecological dyeing process. However, we have to note that the alizarin coloration does not have a good fastness in a high alkalinity medium.

\section{References}

[1] Robiquet C., Nouvelles recherches sur la matière colorante de la garance. Ann. Chim. Phys., 34, 1827, pp 225-253.
[2] Rochleder Ueber Krapp, das Kraut von Asperula odorata und China nova. Liebigs. Ann. Chem., 78, 1851, pp 246-248.

[3] Goverdina C. H., Derksen, Teris A. Van Beek, "Rubia tinctorum L" Studies in Natural Products Chemistry, 26, Part G, 2002, pp 629-684 doi: 10.1016/S1572-5995(02)80016-3

[4] Goverdina C. H, Derksen, Thesis "Analysis and isolation of anthraquinones from madder roots (Rubia tinctorum)", ISBN 90-5808-462-0, 2001, p 89.

[5] Goverdina C. H. Derksen, Thesis "Analysis and isolation of anthraquinones from madder roots (Rubia tinctorum)", ISBN 90-5808-462-0, 2001, pp 17-18.

[6] Peters R. H., “Textile Chemistry”, (M. N. Emelyanova, L. G. Kafton, A. G. Novaradovsky, Eds.), Legprombitizdat, Moscow, 2, 1989, p 122.

[7] Kritcheivsky G. E., Kortchaguine, M. V., Sinakhov, A. V., "Chemical Technologie of Textile Materiel", Eds. Legprombitizdat, Moscow, 1985, p 334-335.

[8] Saphonov V. V, "Chemical Technologie and finishing textile equipment", Eds. Textile University of Moscow, A. H. Kociguin, 2012, p 200.

[9] Chemchame, Y., Errabhi, A., Makhloufi A., "Optimization of the Dyeing Conditions for Wool Fiber with Natural Indigo Using the Argan's Pulp", American Journal of Chemistry and Application, 2, No. 5, 2015, pp 70-74.

[10] Bellakhdar J., «La Pharmacopée marocaine traditionnelle: Médecine arabe ancienne et savoirs populaires», Paris, Ibis Press 1997.

[11] Fellat Z. K., Smoughen S., and R. Maurin R., «Etude de la pulpe du fruit de l'arganier (argania spinosa) du Maroc. Matières grasse et latex» Actes Inst. Agron. Vet. 1987, p 7.

[12] M. Faez M. «Modélisation de la répartition du transfert des métaux lourds et des oligoéléments dans les sols forestiers, l'huile d'argan et dans les différentes parties d'arganier», Thèse d'état, Fac. Sci. Unv. Mohamed V Agdal-Rabat-Maroc, 2012. 